Rafał Matwiejczuk

Uniwersytet Opolski

e-mail: r.matwiejczuk@uni.opole.pl

\title{
THE DEVELOPMENT OF BUSINESS LOGISTICS CONCEPT. FROM OPERATIONAL MANAGEMENT OF LOGISTICS PROCESSES TO THE INTEGRATED FLOW MANAGEMENT WITHIN THE SUPPLY NETWORK
}

\begin{abstract}
Background: Firms constantly search for ways enabling them to achieve and maintain longterm competitive advantage. Among the most significant concepts influencing the achievement of such an advantage by a firm, an important role is played by the business logistics concept. The aim of the chapter is to identify the most important stages of the logistics concept development, ranging from the operational management of logistics processes to the integrated flow management throughout the entire supply network.

Methods: The chapter has a conceptual character. A review of significant works devoted to the development of the logistics concept in business was carried out. Within the chapter there is also a methodical attempt concerning the consecutive logistics concepts (i.e. first logistics concept, second logistics concept, etc.) related to its development towards the flow management in the entire supply network.
\end{abstract}

Results: Within the logistics concept development one may indicate five main stages, typically named as the consecutive logistics concepts - the first logistics concept, the second logistics concept, etc. Within the first concept, logistics "cuts through" the traditional functional areas of a firm, i.e. procurement, production and distribution. Logistics is then perceived as a service function of a firm, whose main task is to secure the desired availability of materials and goods in accordance with the customers' needs and expectations. The second logistics concept emphasizes the importance of the coordination function in the area of goods flows. Within this concept the most important logistics' goal is to optimize the structure of goods flows along the entire value creation network, as well as to reduce the suboptimization of individual activities in the entire flow structure. Within the third concept logistics is perceived as a flow-oriented business management. In this concept the main attention is paid to management functions concerning the individual business management subsystems (planning, organizing, etc.). Within the fourth concept, logistics is perceived as a flow-oriented management across the 
entire supply chain and value creation system. In this concept logistics is a key part of supply chain management, and supply chain management itself is perceived as the most advanced stage of logistics development and integration. Finally, the fifth logistics concept relates to the most significant and expressive tendencies of supply chains and value chains integration towards the logistics networks and supply networks. Logistics is then perceived as a business concept integrating value chains in the form of global networks.

Conclusions: The concept of business logistics is constantly developing towards the managerial direction. The symptom of such development is the perception of business logistics as a concept of flow management on the scale of: (1) firm, (2) supply chain, and (3) supply network. These symptoms may be perceived as so-called managerial re-evaluations of the logistics concept within business management.

Keywords: logistics, logistics processes, logistics concept, flow management, supply chain, supply network.

\section{INTRODUCTION}

Firms are constantly searching for ways enabling them to achieve and maintain the strong, sustained, long-term competitive advantage. One of the most significant concepts affecting the competitive advantage achievement by a firm or even the entire supply chain / supply network is the business logistics concept. The aim of the chapter is to identify the most important stages of the logistics concept development, from the operational management of logistics processes to the integrated flow management throughout the entire supply network.

This is the conceptual chapter. In particular, within the chapter the review of the significant works related to the logistics concept development was carried out. There is also a methodical attempt concerning the consecutive logistics concepts - first logistics concept, second logistics concept, etc. - related to business logistics concept development towards the integrated flow management within the entire supply network.

\section{THE MOST SIGNIFICANT CHARACTERISTICS OF THE LOGISTICS CONCEPT DEVELOPMENT}

The place and role of the logistics concept in management is demonstrated by the results of research carried out by globally recognized researchers, including - among others $-\mathrm{M}$. 
Dehler [2001], B. Mikus [2003], I. Göpfert [2006], G. Prock1 [2007], P. Klaus [2009], and W. Delfmann et al. [2010]. The results of this research confirmed the growing importance of the concept of logistics in broadly understood business management, in particular in achieving the expected market and economic outcomes by the firm, which are the symptoms of its success, as well as in creating the basis for achieving long-term competitive advantage built on the firm strategic potentials, including logistics potentials of success [Matwiejczuk 2014; Matwiejczuk 2015].

As P. Blaik points, the "general" concept of development belongs to the categories commonly used in various contexts, with different intentions and meanings. One may often get the impression that those dealing with the issue of development assume its clear understanding and obvious significance in advance, which results in general treatment, and following this superficial approach to the merits of the matter to be addressed. This can also be seen in relation to the treatment - both in theory and in practice - of logistics development issues. Hence, taking into consideration a closer identification of logistics development aspects, it is worth to attempt an in-depth interpretation of the essence of the development concept as a capacious - in terms of structure and dynamics - category, pointing to its immanent characteristics in the form of [Blaik et al. 2013]: (1) premises of the logistics development, (2) symptoms of the logistics development, (3) results of the logistics development, and (4) vision of the logistics development in the future (figure 1).

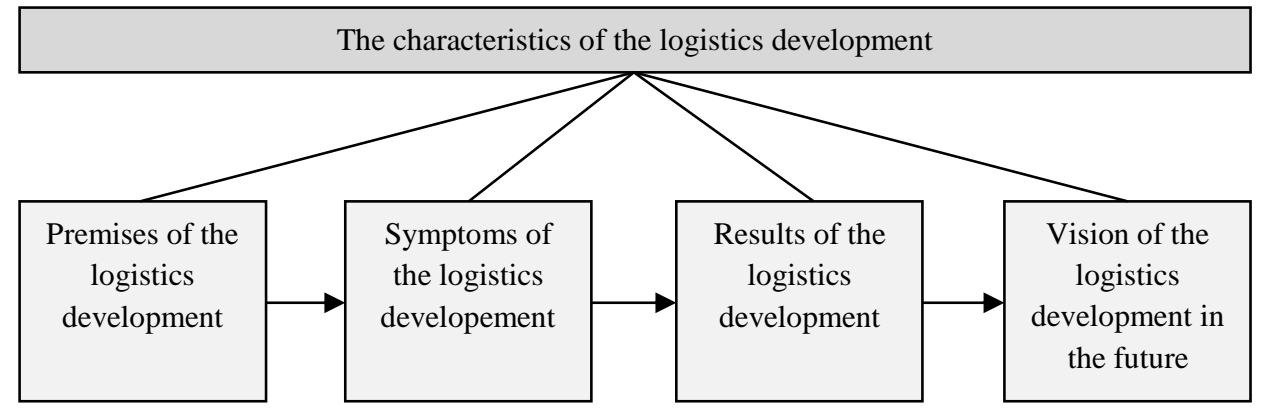

Fig. 1. The structure and dynamics of the logistics development - the general attempt. Source: [Blaik et al. 2013].

The development characteristics presented in the chapter also define the structure for identifying logistics development, giving it the desired level of details within the considerations as well as some necessary transparency. In addition, these characteristics indicate the need and opportunity for a more thorough assessment of the scope and effectiveness of the existing changes 
as well as proposed changes and opportunities for a long-term development. This assessment, in turn, allows the formulation of logistics development strategy in a given situation, taking into account and using the existing premises and possibilities, as well as creating the appropriate and long-term driving forces for its development. It is very important to know the current trends and the strategic importance of the determinants of logistics development within the global scale.

The dynamic development of logistics has been constantly going on since the mid-twentieth century. As a result, the strategic importance of logistics in the practice of business management is constantly increasing, which is associated with significant changes concerning the internal and external conditions for business management. These changes, as well as the corresponding processes and challenges, reveal themselves with varying degrees of strength. This is evidenced by the varied levels and standards of contemporary logistics and its place within business management system [Blaik 2017a].

\section{FIVE STAGES IN BUSINESS LOGISTICS CONCEPT DEVELOPMENT}

In the business logistics development one may notice a shift in the focus from logistics perceived as a concept oriented at the transformation of activities within the area of goods flows towards logistics perceived as an integrated concept of materials, goods and information flows management, both in the firm (business) scale as well as in the entire supply chain or even the entire supply network scale. The basic feature of the logistics concept is the integration and optimization of flow processes and systems. In recent years logistics has been also developing towards a multidimensional scientific discipline (subdiscipline), characterized by the dynamics of development and integration as well as management reevaluations [Blaik 2017b].

Within the logistics concept development one may indicate five main stages (figure 2). These stages are often named as the consecutive logistics concepts, i.e. the first logistics concept, the second logistics concept, etc. The detailed characteristics of the above concepts indicate the growing significance of logistics within contemporary business as well as supply chain or even supply network management.

As P. Blaik emphasizes, the identification and isolation of subsequent stages of logistics concept development is relative, as there are no clear and unambiguous transitions and divisions between the individual stages. Each subsequent development stage is based on the achievements and experience of the earlier stages of development and means a significant broadening of knowledge with new management capabilities and skills [Blaik 2017a; Blaik 2017b]. A brief 
description of the individual stages of logistics concept development is presented in the following chapters.

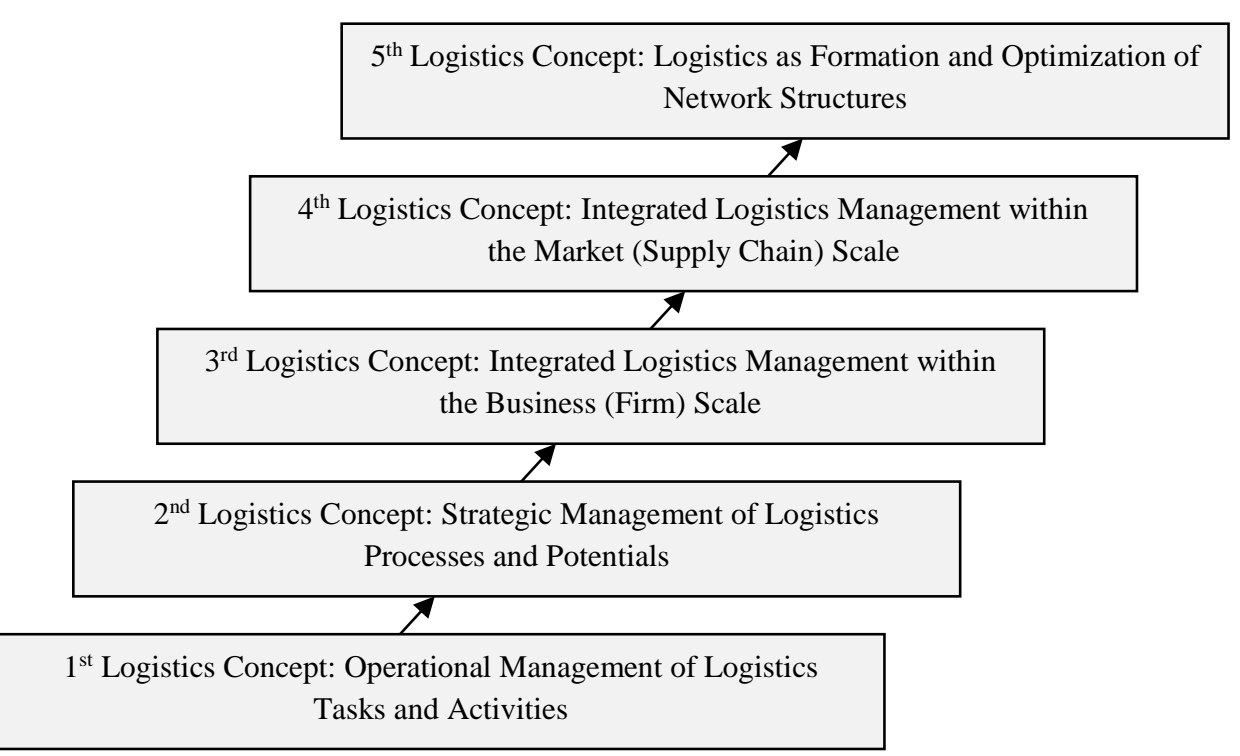

Fig. 2. Five stages in logistics concept development.

Source: Based on [Blaik et al. 2013; Blaik 2017a; Blaik 2017b].

\section{FIRST LOGISTICS CONCEPT: LOGISTICS AS A SPECIALIZED CROSS- SECTION FUNCTION WITHIN THE FIRM ORIENTED FOR THE TRANSFORMATION ACTIVITIES. OPERATIONAL MANAGEMENT OF LOGISTICS TASKS AND ACTIVITIES}

The first logistics concept means that logistics "cuts through" the traditional business functions, i.e. functional areas of a firm comprising procurement, production and distribution. Within this concept logistics is perceived and understood as a service function of a firm. The main task assigned to logistics is to secure the desired availability of materials and goods, taking into consideration the customers' needs and expectations.

The first concept of logistics is associated with understanding logistics as knowledge about transfer activities [Prockl 2007]. Within the first stage of development, logistics is defined as functionally specialized activities of transformation of goods (concerning changes in the characteristics of goods) and a new function related to specific benefits in terms of both effectiveness and efficiency in the area of goods flows. Bearing in mind the cross-sectional nature of logistics, it permeates traditional functional areas in which there are manifestations of transformation, which allows achieving a specific state of integration of homogeneous activities 
and cooperation results. In the first concept of logistics specific functions are assigned to logistics in the areas of integrating, planning, organizing and controlling goods transformation activities. This often means treating logistics as a firm function whose task is - first of all - to secure the appropriate availability of materials and goods in accordance with the needs and expectations of customers [Blaik 2017a; Blaik 2017b].

Operational management of logistics tasks and activities usually means focusing on a relatively short time horizon. A number of implemented tasks concern the so-called "routine operations", also referred to as "organizational routines". Effective and efficient implementation of logistics tasks and activities is mainly assessed on an ongoing basis in terms of achieving operational goals.

\section{SECOND LOGISTICS CONCEPT: LOGISTICS AS A COORDINATION FUNCTION CONCERNING FLOW ORIENTED ACTIVITIES OF VALUE CREATION. STRATEGIC MANAGEMENT OF LOGISTICS PROCESSES AND POTENTIALS}

The most significant issue of the second logistics concept concerns the importance of the coordination function in the area of goods flows. It means that within this concept the most important logistics goal is to optimize the goods flows structure along the entire value creation network, as well as to reduce the suboptimization of individual activities in the entire flow structure [Blaik 2017a; Blaik 2017b].

In the second concept of logistics the key role is assigned to the coordination function in the process of creating value in the area of goods flows. Such coordination does not appear in the first logistics concept. The second logistics concept emphasizes that the most important issue concerning logistics relates to the optimization of the structure of the goods flows along the entire value creation network as well as to reducing the desires to suboptimize individual activities in the structure of flows and functional areas [Mikus 2003].

As a result, the second concept of logistics means treating logistics as "knowledge about the coordination and integration of functions" of a firm in the area of flows. The goal of logistics is primarily to shape the individual activities towards a whole (system), where the focus is on optimizing total costs in the flows of materials, goods and information, as well as ensuring an appropriate level and structure of customer service [Prockl 2007]. 
An important characteristics (feature) of logistics in terms of the second concept is the assumption that coordination tasks are accomplished through management activities, which is manifested, among others, in perceiving and treating the business logistics more and more clearly as an instrument as well as an important area of shaping and coordinating processes both within the firm and the market (supply chain) [Blaik 2017a; Blaik 2017b].

\section{THIRD LOGISTICS CONCEPT: LOGISTICS AS FLOW ORIENTED BUSINESS MANAGEMENT. INTEGRATED LOGISTICS MANAGEMENT WITHIN THE BUSINESS (FIRM) SCALE}

The third concept of logistics assumes that the logistics is a flow-oriented business management. Within the third logistics concept the central point of attention is related to management functions concerning the individual business management subsystems (planning, organizing, etc.). Logistics is then referred to as the "sub-discipline of management science" [Göpfert 2006]. In the opinion of J. Weber and S. Kummer, within the third logistics concept the focus of logistics management lies in the anchoring of the principle of flow orientation in individual firm (business) management systems [Weber, Kummer 1998].

P. Blaik points out that within the third concept logistics is seen as a special management concept that determines flow-oriented firm (business) management. At this stage of development logistics is revealed in a specific management perspective, including a new quality based on the logistic treatment of the value creation process. In this sense the concept of logistics is integrated into the firm (business) management system. When isolating and interpreting this concept of logistics, the use of flow orientation in analyzing and solving problems in the entire firm structure at all levels of management is emphasized. This accelerates and strengthens the process of shaping and consolidating awareness of the nature of the contemporary logistics perceived as a concept of materials, goods and information flows management in the firm scale. The premise for this perception of logistics is improving the management system by introducing process-oriented forms of organization in the firm that mitigate the effects of emerging contacts and reduce the need for coordination [Blaik 2017a; Blaik 2017b]. 


\section{FOURTH LOGISTICS CONCEPT: LOGISTICS AS FLOW ORIENTED SUPPLY CHAIN MANAGEMENT AND VALUE CREATION SYSTEM MANAGEMENT. INTEGRATED LOGISTICS MANAGEMENT WITHIN THE MARKET SCALE}

The fourth logistics concept presents business logistics as a flow-oriented management concerning the entire supply chain as well as the entire value creation system. Within this concept logistics constitutes a significant part of supply chain management. Simultaneously, supply chain management is perceived as the most advanced level of logistics development and integration.

Supply chain management is a very dynamically developing concept of managing materials, goods, information and financial resources flows. Its main task is to optimally shape flow processes along the entire supply chain. Therefore, as it was mentioned above, the supply chain management concept can be treated as the most advanced stage of logistics development and integration, referred to as the fourth logistics concept [Weber 2002; Schulze 2007].

The new quality associated with a high level of integration within the supply chain management concept is reflected in the inter-organizational perspective and integration of flows of goods and information along the subsequent steps of value added creation, consistent orientation towards meeting customer needs and solving their problems, as well as an integrated managerial and process approach. The supply chain comprises a network of firms (businesses) involved, through relationships with its suppliers and customers, in various processes and activities, leading to value creation resulting in products and services provided to customers. The most important subject of the supply chain management concept concerns the issue of integrated flows along the value creation chain, from initial raw materials suppliers, through manufacturing and trading companies, to ultimate customers. As a result, the main goal of the supply chain management concept is to create and deliver the highest value to the customer at the lowest costs for the entire supply chain [Blaik 2017a; Blaik 2017b].

FIFTH LOGISTICS CONCEPT: LOGISTICS AS FORMATION AND

OPTIMIZATION OF NETWORK STRUCTURES. LOGISTICS NETWORK

MANAGEMENT AND SUPPLY CHAIN / NETWORK MANAGEMENT AS THE

TOOLS COORDINATING BUSINESS RELATIONS AMONG NETWORK PARTICIPANTS 
The fifth logistics concept is, so far, the most developed concept concerning flow management. This concept relates to the most significant and expressive tendencies of supply chains as well as value chains integration towards the logistics networks and supply networks. Logistics is then perceived as a business concept integrating value chains in the form of global networks [Blaik 2017a; Blaik 2017b].

It seems that the fifth concept of logistics is still beginning to evolve. Increasingly clearer and more important trends concerning the integration of supply chains and value chains form the basis for shaping and developing multi-dimensional logistics networks and supply networks, characterized by global scope. Logistics as a concept integrating value chains in the form of global networks is not only a modern instrument of contemporary management affecting the building of business success and creating firm competitive advantage [Matwiejczuk 2014; Matwiejczuk 2015], but also is becoming an increasingly important part of the global economy associated with global processes of materials, goods and information flows.

At the same time, the fifth logistics concept very strongly refers to the scientific dimension of logistics positioned as a scientific sub-discipline within the management sciences. In research conducted both in Poland [Blaik 2017b] and in the world [Delfmann et al. 2010], the scientific nature of logistics is increasingly emphasized, in relation to the aspirations of perceiving the concept of logistics not only in practical terms, but also in theoretical and methodological terms.

\section{CONCLUSION}

The chapter presented the most important stages in the logistics concept development. The concept of logistics is permanently evolving. In particular, one may notice the growing importance of business logistics perceived not only as a concept of materials, goods and information flows management, but also as a determinant of business success and an instrument (tool) for creating competitive advantage of firms as well as supply chains and networks. In addition to the practical dimension of the concept of logistics, its theoretical and scientific dimension, associated with the perception of logistics as a sub-discipline of management sciences, is constantly developing.

\section{REFERENCES}

Blaik P., 2017a, Logistyka. Koncepcja zintegrowanego zarządzania, PWE, Warszawa. 
Blaik P., 2017b, Rozwój logistyki w kierunku dyscypliny nauki, Gospodarka Materiałowa i Logistyka, 9, 2-10.

Blaik P., Bruska A., Kauf S., Matwiejczuk R., 2013, Logistyka w systemie zarządzania przedsiębiorstwem. Relacje i kierunki zmian, Polskie Wydawnictwo Ekonomiczne, Warszawa.

Dehler M., 2001, Entwicklungsstand der Logistik. Messung - Determinanten Erfolgswirkungen, DU-Verlag, Wiesbaden.

Delfmann W., Dangelmaier W., Günthner W., Klaus P., Overmeyer L., Rothengatter W., Weber J., Zentes J., Working group of the Scientific Advisory Board of German Logistics Association (BVL), 2010, Towards a science of logistics: cornerstones of a framework of understanding of logistics as an academic discipline, Logistics Research, 2, 57-63, DOI: 10.1007/s12159-010-0034-5.

Göpfert I. (ed.), 2006, Logistik der Zukunft - Logistics for the Future, Verlag Gabler, Wiesbaden.

Klaus P., 2009, Logistics research: a 50 years' march of ideas, Logistics Research, 1, 53-65, DOI: $10.1007 / \mathrm{s} 12159-008-0009-\mathrm{y}$.

Matwiejczuk R., 2014, Kompetencje logistyki w tworzeniu przewagi konkurencyjnej przedsiębiorstwa, Wydawnictwo Uniwersytetu Opolskiego, Opole.

Matwiejczuk R., 2015, Logistyczne potencjały sukcesu w tworzeniu przewagi konkurencyjnej przedsiębiorstwa, [in:] Strategie i logistyka w warunkach kryzysu, (ed.) J. Witkowski, A. Skowrońska, Prace Naukowe Uniwersytetu Ekonomicznego we Wrocławiu, nr 382, Wydawnictwo Uniwersytetu Ekonomicznego we Wrocławiu, Wrocław, 363-375.

Mikus B., 2003, Strategisches Logistikmanagement. Ein markt-, prozess- und ressourcenorierties Konzept, Deutscher Universitäts Verlag / GWV Fachverlage, Wiesbaden.

Prockl G., 2007, Logistik-Management im Spannungsfeld zwischen wissenschaftlicher Erklärung und praktischer Handlung, Deutscher Universitäts Verlag / GWV Fachverlage, Wiesbaden.

Schulze M., 2007, Prozesskostenorientierte Gestaltung von Wertschöpfungsketten, DU-Verlag, Wiesbaden.

Weber J., 2002, Logistik - und Supply Chain Management, Schäffer-Poeschel Verlag, Stuttgart. 
Weber J., Kummer S., 1998, Logistikmanagement. Führungsaufgaben zur Umsetzung des Flußprinzips im Unternehmen, Schäffer-Poeschel Verlag, Stuttgart.

A. Kolinski et al. (eds.), Contemporary challenges in supply chains, Vol. 1, https://doi.org/10.17270/B.M.978-83-66017-88-7.2 